\title{
Call for comments: climate and clean air responses to covid-19
}

\author{
Shardul Agrawala ${ }^{1} \cdot$ Markus Amann ${ }^{2} \cdot$ Graciela Binimelis de Raga $^{3} \cdot$ Nathan Borgford-Parnell $^{4} \cdot$ \\ Michael Brauer ${ }^{5} \cdot$ Harry Clark $^{6} \cdot$ Lisa Emberson $^{7} \cdot$ Andy Haines $^{8} \cdot$ Jiang Kejun $^{9} \cdot$ Nino Künzli ${ }^{10}$. \\ Johan Kuylenstierna ${ }^{7} \cdot$ Rodolfo Lacy $^{1} \cdot$ Jian Liu $^{11} \cdot$ Yacob Mulugetta $^{12} \cdot$ Shonali Pachauri $^{2}$.

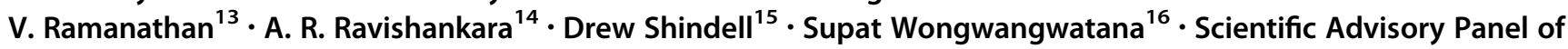 \\ the Climate and Clean Air Coalition and Invited Experts
}

Received: 3 May 2020 / Revised: 3 May 2020 / Accepted: 14 May 2020 / Published online: 26 May 2020

(C) Swiss School of Public Health (SSPH+) 2020

Much of the world is seeing significant reductions in many air pollutant and greenhouse gas emissions due to efforts to stem the covid-19 pandemic (Han et al. 2020; He et al. 2020). This is a stark confirmation of the contribution of our everyday activities to sources of emissions of the air pollutants that we breathe and the greenhouse gases that drive global warming. The speed with which emissions have fallen shows how quickly we can improve our environment when motivated and how vulnerable we are living in degraded environments.

It is important to recognize that these changes are not unexpected. Similar decreases in air pollution and greenhouse gas emissions have occurred due to short-term events such as clean air policies put in place for the 2008 Beijing Olympics, and the 2008-2009 global recession (Castellanos and Boersma 2012; Tong et al. 2016) as well as from long-term air quality management policies (Dedoussi et al. 2020).

As with previous shocks, we know that pollution continues to occur even with significant government-imposed constraints. For example, pollutants from transport and industrial sectors have decreased but not from residential or agricultural sources. Moreover, some pollutants, like ozone, result from secondary atmospheric processes resulting in nonlinear links between reduced emissions and ambient concentrations (Wang et al. 2020).

While these decreases result in public health benefits from improved air quality, they come at the unacceptable cost of thousands of deaths, rapidly increasing unemployment, and staggering economic dislocation. And,

Disclaimer: Any opinions reflected in this comment are those of the authors. They do not purport to reflect the opinions or views of the Climate and Clean Air Coalition or its Partners.

Extended author information available on the last page of the article at the individual level, some families may be exposed to even greater pollution levels (e.g. from increased openburning cookstove meals) during the lockdown.

There is also much we are continuing to learn about potential links between exposure to poor air quality and vulnerability to the impacts of covid-19 as well as other important socio-economic aspects which could increase vulnerability. However, there is already strong evidence that for respiratory infections in general (Mehta et al. 2013), air pollution worsens their severity, with some evidence of an interaction from SARS (Cui et al. 2003) as well as emerging studies on the air pollution and covid-19 (Wu et al. 2020). Given that economic activity has already re-started while the pandemic is still underway, it is more than prudent to consider improved air quality as an additional measure to help reduce the burden placed on healthcare systems.

As our understanding of these links improve, it will give us even greater motivation to commit to long-term sustainable energy and environmental policies. Despite the acute challenge of this global pandemic, we cannot allow it to compromise our efforts to tackle the world's inescapable, linked, and ongoing challenges of climate change, poor air quality, unsustainable development, and the loss of biodiversity.

As was the case with past shocks, current emissions reductions are not sustainable and will return to pre-event levels unless we use the emergence from the economic downturn as an opportunity for transformational change (Peters et al. 2012). How we decide to stimulate the economy in response to the covid-19 virus can have enormous impacts on these longstanding global threats.

As governments apply economic stimulus efforts, it is more important than ever that these make the connection between health, air pollution, climate, and the environment. By addressing climate, air pollution, and sustainable development as an integrated problem, we can identify 
technologies, lifestyle changes, and policy solutions which achieve multiple near-term benefits efficiently, sustainably, and often at lower cost than solutions that no not consider both the economy and the environment.

This has always been the core message of the Climate and Clean Air Coalition. Many people in the world, some for the first time, are inadvertently experiencing what it is like to live with clean air; this benefit does not have to come at the expense of our security and economic future.

We identified many of the solutions that deliver economic and social objectives while simultaneously protecting our air and climate. These include investing in:

- development, deployment, and integration of clean renewable energy instead of fossil fuels, ensuring equitable and affordable access for all;

- measures which reduce short-lived climate pollutants such as addressing emissions from the burning or collection of municipal solid waste; these measures are often low/no-cost, and quickly achieve multiple nearterm economic, public health, and social benefits;

- policies and regulations which improve indoor air quality by incentivizing energy access and energy efficiency of buildings and appliances;

- preserving our forests and other natural sinks, as well as in expanding them;

- sustainable food systems, reduced food waste, and the promotion of healthy diets;

- a more local, circular, and low-carbon economy incentivising safe reuse, remanufacturing, and recycling of products;

- more resource efficient, sustainable, and resilient supply chains;

- sustainable transport systems including encouraging active travel, work from home, and implementing policies to reduce daily commuting and reducing business travel;

- invest in knowledge institutions, especially in the Global South, to strengthen their capability to produce high quality and context relevant analyses and build the requisite human resources.

Right now, policymakers and leaders are looking for clear guidance on how to build back quickly from this pandemic and create resilient conditions in our communities and societies to avoid future economic recessions. To act they need concrete examples and supporting information about the transformations and investments needed to reduce emissions while stimulating the economy.

We are issuing a call to the global scientific and policy community to come together and provide the guidance and evidence to, not just build back, but Build Back Better.

\section{Additional questions}

- What role might air quality and climate policy, including short-lived climate pollutant policy, play in the recovery plans following the pandemic, including plans to speed the economic recovery?

- What are the similarities and the difference between the pandemic and the risk from climate impacts, including the importance of being prepared for the risk and taking precautionary measures in advance of impacts; the nonlinear nature of both risks; and the potentially catastrophic consequences for society, including our social, civic, and economic systems?

- What can we learn from the communication of the respective risks of the pandemic, climate, and air quality impacts?

- The virus requires physical distancing and a radical alteration of our everyday social, economic, and political lives, but it is also showing us how closely interconnected we are. We can now see, both as individuals and as a society, how capable we are of making major changes, if the safety and sustainability of our society is at stake. What can we learn from the response to covid-19, and previous shocks, which we can use for action on climate and air pollution?

Acknowledgements The Climate and Clean Air Coalition (www.cca coalition.org) is the only global effort that unites governments, civil society and private sector, committed to improving air quality and protecting the climate in the next few decades by reducing short-lived climate pollutants. The Coalition supports the achievement of transformative actions, policies, and regulations that lead to substantial reductions in these pollutants. The Coalition's Scientific Advisory Panel is made up of 15 international experts who advise the Coalition on scientific matters related to short-lived climate pollutants, air pollution, and near-term climate change. The Coalition's Secretariat is hosted by the United Nations Environment Programme.

\section{Compliance with ethical standards}

Conflict of interest The authors declare that they have no conflict of interest.

\section{References}

Castellanos P, Boersma KF (2012) Reductions in nitrogen oxides over Europe driven by environmental policy and economic recession. Sci Rep 2:265. https://doi.org/10.1038/srep00265

Cui Y, Zhang ZF, Froines J et al (2003) Air pollution and case fatality of SARS in the People's Republic of China: an ecological study. Environ Health 2:15

Dedoussi IC, Eastham SD, Monier E et al (2020) Premature mortality related to United States cross-state air pollution. Nature 578:261-265

Han Y, Lam JC, Li VO, Guo P, Zhang Q, Wang A, Crowcroft J, Wang S, Fu J, Gilani Z, Downey J (2020) The effects of outdoor 
air pollution concentrations and lockdowns on Covid-19 infections in Wuhan and other provincial capitals in China. Preprints. https://doi.org/10.20944/preprints202003.0364.v1

He G, Pan Y, Tanaka T (2020) COVID-19, city lockdown, and air pollution: evidence from China. medRxiv. https://doi.org/10. 1101/2020.03.29.20046649

Mehta S, Shin H, Burnett R et al (2013) Ambient particulate air pollution and acute lower respiratory infections: a systematic review and implications for estimating the global burden of disease. Air Qual Atmos Health 6(1):69-83

Peters GP, Marland G, Quéré CL et al (2012) Rapid growth in $\mathrm{CO}_{2}$ emissions after the 2008-2009 global financial crisis. Nat Clim Change 2:2-4

Tong D, Pan L, Chen W et al (2016) Impact of the 2008 Global Recession on air quality over the United States: implications for surface ozone levels from changes in $\mathrm{NO}_{\mathrm{x}}$ emissions. Geophys Res Lett 43(17):9280-9288

Wang P, Chen K, Zhu S et al (2020) Severe air pollution events not avoided by reduced anthropogenic activities during COVID-19 outbreak. Resour Conserv Recycl 158:104814

Wu X, Nethery RC, Sabath BM et al (2020) Exposure to air pollution and COVID-19 mortality in the United States. medRxiv (non peer-reviewed preprint article). https://doi.org/10.1101/2020.04. 05.20054502

Publisher's Note Springer Nature remains neutral with regard to jurisdictional claims in published maps and institutional affiliations.

\section{Affiliations}

\section{Shardul Agrawala ${ }^{1} \cdot$ Markus Amann $^{2} \cdot$ Graciela Binimelis de Raga $^{3} \cdot$ Nathan Borgford-Parnell $^{4} \cdot$ Michael Brauer ${ }^{5} \cdot$ Harry Clark $^{6} \cdot$ Lisa Emberson $^{7} \cdot$ Andy Haines $^{8} \cdot$ Jiang Kejun $^{9} \cdot$ Nino Künzli $^{10}$. Johan Kuylenstierna ${ }^{7} \cdot$ Rodolfo Lacy $^{1} \cdot$ Jian Liu $^{11} \cdot$ Yacob Mulugetta $^{12} \cdot$ Shonali Pachauri $^{2} \cdot$ V. Ramanathan ${ }^{13}$. A. R. Ravishankara ${ }^{14}$. Drew Shindell ${ }^{15}$. Supat Wongwangwatana ${ }^{16} \cdot$ Scientific Advisory Panel of the Climate and Clean Air Coalition and Invited Experts}

Nathan Borgford-Parnell

Nathan.borgford-parnell@un.org

Shardul Agrawala

Shardul.Agrawala@oecd.org

Markus Amann

amann@iiasa.ac.at

Graciela Binimelis de Raga raga.graciela@gmail.com

Michael Brauer

michael.brauer@ubc.ca

Harry Clark

harry.clark@nzagrc.org.nz

Lisa Emberson

1.emberson@york.ac.uk

Andy Haines

andy.haines@1shtm.ac.uk

Jiang Kejun

kjiang@eri.org.cn

Nino Künzli

nino.kuenzli@swisstph.ch

Johan Kuylenstierna

johan.kuylenstierna@york.ac.uk

Rodolfo Lacy

Rodolfo.LACY@oecd.org

Jian Liu

jian.liu@un.org

Yacob Mulugetta

yacob.mulugetta@ucl.ac.uk

Shonali Pachauri

pachauri@iiasa.ac.at
V. Ramanathan

vram@ucsd.edu

A. R. Ravishankara

A.R.Ravishankara@colostate.edu

Drew Shindell

drew.shindell@duke.edu

Supat Wongwangwatana

supat@ rrcap.ait.asia

Organization for Economic Co-operation and Development, Paris, France

2 International Institute for Applied Systems Analysis, Laxenburg, Austria

3 Universidad Nacional Autónoma de México, Mexico City, Mexico

4 Climate and Clean Air Coalition, Paris, France

5 School of Population and Public Health, University of British Columbia, Vancouver, Canada

6 New Zealand Agricultural Greenhouse Gas Research Centre, Palmerston North, New Zealand

7 Stockholm Environment Institute, York, UK

8 London School of Hygiene and Tropical Medicine, London, UK

$9 \quad$ Energy Research Institute, National Development and Reform Commission, Beijing, China

10 Swiss Tropical and Public Health Institute, Bern, Switzerland

11 UN Environment Programme, Nairobi, Kenya

12 Department of Science, Technology, Engineering and Public Policy, University College London, London, UK 
13 Scripps Institution of Oceanography, University of California San Diego, La Jolla, USA

14 Department of Atmospheric Science, Colorado State University, Fort Collins, USA
15 Nicholas School of the Environment, Duke University, Durham, USA

16 Faculty of Public Health, Thammasat University, Bangkok, Thailand 